\title{
Scientization of Science
}

\author{
Yoichiro P. Murakami
}

\section{Introduction}

Science is science. Science could not be scientized. Is this assertion true? As is well-known, the word "science" stems from a Latin word "scientia", original meaning of which was knowledge. Consequently the word of science used to have the same meaning as knowledge.

Historically speaking, it is true. In English as well as in French, the meaning of "science" was knowledge in general. That means science did not have the meaning that the word now has. Today science is not knowledge in general, but a special kind of knowledge which has its own universe of discourse, its own objects, its own methodology, and its own institution. It is much narrower than knowledge. Then when and how science, or the meaning of science, became narrower? By what process did the tansformation of the meaning of science take place? In other words, when and how "science" became science? To answer these questions is to elucidate what the scientization of science is.

\section{Coinage of the Word "scientist"}

It is rather well-known that the word "scientist" was coined by W. Whewell around 1840. Until then English speaking people did not have a word to designate persons who are involved in science or scientific research of today's sense. Of course, there used to be the word "science" in English as well as in French. It did not, however, convey its present meaning, but only meant knowledge in general. Of course the word could mean knowledge in general even today, but it would be quite exceptional case. Consequently, the meaning of the word "science" must be changed and narrowed from the one used to be at a certain stage of Western history. That change must be related to the emergence of science of today's sense.

It can be said that the suffix "... ist" means "a person who is engaged in something". Besides that, however, the "something" should be not a wide and broad field but a narrow and limited one. In other words, "... ist" almost always means "a specialist" in something. This can be easily understood, if we compare the words "physician" to "dentist", "musician" to "flutist". Then it is rather queer that

Research Center for Advanced Science and Technology, University of Tokyo, Meguro-ku, Komaba 4-6-1, Tokyo 153 
W. Whewell coined "scientist" in terms of combining such a word of wide and broad meaning as science (namely "knowledge") with the suffix "ist". If Whewell had had knowledge in general in his mind when he coined the word, he should have created "scientian" or "scienter" but never "scientist". Actually an English intellectual, T. Huxley was by no means comfortable with this word, and when he was called in late 19th century as a "scientist", he refused to be so. Instead he proposed "a man of science" for his naming. In this case, it can be assumed that what was in his mind was "a man of knowledge", which means that to Huxley the word "science" conveyed its traditional meaning even almost at the end of the century. Another episode of Huxley shows it more clearly. It is told that he said that such an ugly word as "scientist" must have been coined by an American. The ugliness that Huxley felt in this newly coined word may be imagined that the way of the coinage was, or seemed to be at least to him, a violation of the rule above-mentioned. He might have been satisfied with "scientian".

Of course, the man who coined the word was not an analphabetic American, but a genuine British intellectual. He knew well what "... ist" is and what "science" of those days means. Still he dared to combine "scientia" and "... ist" to coin the word. His intention was two-fold, we can assume. On the one hand he was sensitive enough to conceive the emergence of a new societal class of people who are professionally and as an expert engaged in a specific field of knowledge on nature with a specific methodology. He must have an appropriate word to name the emerging class of people. He even wanted to encourage the emergence of that kind of class in the British society, because he believed that emerging "scientists" should make great contribution to the modernization of the United Kingdom. As Charles Bubbage and others Whewell was worried and irritated by lingering unpopurality of "science" (of today's sense) in England, particularly compared to the German speaking areas.

On the other hand he was also sensitive enough to perceive the change of the meaning of the word, science, which around that time presumably began to be applied both for knowledge in general following the traditional way and knowledge of a narrower and specific field. In other words "science" began to be able to designate science of today's sense just around 1840. It means that science appeared to emerge at that time by its scientization.

As we already saw, there was a kind of antipathy among the British intellectuals against such a movement that Whewell was watching and encouraging. Knowledge should be pursued for the sake of itself but not of producing economical gains. One should pursue knowledge because he or she loves it, which means he or she does as an amateur. That used to be a traditional idea on knowledge. A scientist appeared to deal with knowledge or rather only a quite narrow part of knowledge professionally. 
Thus it cannot be said that "scientists" were always welcome even in the latter half of the 19th century particularly in Britain. To understand why, it may be inevitable to survey a history of ideas on knowledge in the West from a new perspective.

\section{Renaissance Reconsidered}

I have a hypothesis upon the idea of the Renaissance, which differs from the usual concept of it and covers the period from the 12th century to the 17th century. This is not the opportunity to extend the idea fully but I would like to refer to it only briefly and roughly within the range of the present discussion on scientization of science. My definition of the Renaissance is the period wherein the West tried to amalgamate Christian faith with learnings imported from outer worlds. In the 12th century the West encountered in the midst of the Reconquista the Greco-RomanoArabic learnings through the Islamic intellectuals, which included Aristotelian philosophy, Euclidean geometry, Ptolemaic astronomy, Khwarizmian algebra, Arabian alchemy and so on. These learnings were entirely new to the West at that time, and they must be translated into Latin from Arabic as well as from Greek so that the intellectuals in the West might understand them. After the translation period which continued almost one and a half century, came the period of digestion and integration of them in terms of combining and amalgamating them with their own Christian faith. The most remarkable result was the establishment of the scholasticism, represented by the knowledge system of Thomas Acquinas. Roughly speaking, the scholasticism was an amalgamation of Christian faith with Aristotelian philosophy. As I will mention later, parallel to this, universities emerged from place to place, in Bolognia, Paris, Oxford and Cambridge for students to study the newly established scholasticism.

In the 15th, 16th and 17th centuries, almost the same process as in the 12th century occurred. In mid 15th century, in Florence, Cosimo di Medici started his Academia Platonica and there enthusiastically had the books translated, which were imported from outside and again quite new and seemingly pagan to the West of those days. Among them there were the books of Hermeticism, Cabalism, and other foreign mystical traditions as well as of Neo-platonistic tradition. Again after the translation period there came the period for their integration and amalgamation with the Western traditional Christianity. This time, however, the results of the amalgamation did not converge like the scholasticism in the 12th and 13th centuries, but diverged with a wide range and in various directions. Not only the works of Copernicus, Kepler, Galileo and Newton but also the ones of Paracelsus, Robert Fludd, Johan von Andreae, Jean Battista della Porta, all of these works were the results of such endeavours of amalgamation. 


\section{Knowledge in the Renaissance 1}

As I mentioned earlier, universities started, as institutes where people could study the newly established scholasticism, in 13th century Europe. Generally they were equipped with four institutions ; college of liberal arts and school of medicine, of law and of theology. Needless to say, there was no school of science. In most cases, the college of liberal arts did not have the right to credit Doctor's degree, whereas other three did, but still it can be said that it was the corpus of universities.

The other three schools were the institutions where students could be trained as an expertise who deals with a special field of knowledge as a professional. Medical doctors, priests and theologians, lawyers, these professions which are related to the three schools have been recognized and evaluated to be high social status among professions. Nevertheless, it is quite important to recognize that the three professions, all of which are closely connected with knowledge, were quite different from other ordinary professions. To help those whom are suffering in society in one way or another, that is the core of the tasks that they were expected to excercise. Furthermore, they should be called and ordered by God to do so, and accept His calling. Clearly the will of God played the main role for somebody to become a doctor, a lawyer or a priest.

It is worth noticing that the money to be given to them was and still is called not as wage, salary etc., but as honorarium. In other words, these three professions are certainly engaged in knowledge pursuing activities, but they were not, of those days at least, the profession where knowledge is involved into the network of production-consumption relations and a fragment of knowledge produced professionally is sold and bought according to the market mechanism. Knowledge should not and could not be sold or bought by means of monetary exchange. Compared to this situation, a department of science of today's university is clearly the place of knowledge production, whereas military, bureaucratic and industrial sectors are the place of knowledge consumption. Between the two a market of knowledge, so to speak, is created which is chiefly governed by money.

Back to the liberal arts, the concept itself was not a product of the West but of Greek. They consist of two different categories; trivium and quadrivium, and each of them again is divided into three and four ; logic, rhetoric and grammar on the one hand, and on the other, astronomy, arithmetic, geometry and music. This way of division of knowledge can be dated back to the Pythagorian school.

When the products of Greco-Romano-Arabic philosophy were introduced in full scale through the process of the 12th Century Renaissance to the West, as I mentioned above, they were amalgamated with then existing Christian theology which was rather naive compared to the one created after the 12th Century Renaissance. The amalgamation created a new system of knowledge, which is 
called the scholasticism as I wrote before, The formation of the scholasticism resulted in reorganization of knowledge itself and the inauguration of social institution for the pursuit of knowledge. The establishment of universities was one of the most remarkable results of it.

Under the new scholastic interpretation, the concept of liberal arts, which became the core curriculum of the newly established universities, was also transformed from the original form in Greek or in succeeding Roman and Arabian cultural contexts. In the scholasticism, the aim of knowledge pursuing activities was clearly defined. That is, knowledge should be pursued for the purpose of better understanding of the Holy Design, the wills of God, the Creation and so on. Then the trivium of liberal arts, each of which is related to language, was now considered to cultivate the literacy for reading, understanding and extending the content of Holy Scripture written by God. Quadrivium, each of which is related to Nature, to cultivate the literacy for reading, understanding and extending what is written in the Second Book by God; Nature.

It may be questioned whether music is related to Nature. One must be careful what music is here as one subject of the quadrivium. Although there is a small overlapping between music in that sense and music of today, they are fundamentally quite different in many ways. Music in that sense is not an art but a field of knowledge, which deals with Nature in such a sense that a string, a tube or whatever else, divided with the ratio of one to one makes one octave higher tone than the one made by the string of the original length. With the ratio one to two, we can get the 5th of the original tone, etc,.

These musical understandings of tones are a part of knowledge on Nature. Moreover, it has something to do with arithmetical knowledge in considering the arithmetical ratio, with geometrical knowledge in dividing a line or a figure made by a line, and even with astronomical knowledge in applying the calculated data to astronomical theories just like what J. Kepler did in his Harmonice mundi published in 1619 .

These can illustrate that music in that sense was a field of knowledge and counted as one of subjects taught in universities.

Within the scholastic interpretation, these subjects dealing with knowledge on Nature were regarded as some endeavours to read and understand what is written in His Second Book, Nature. In short, trivium was to cultivate the literacy for reading the first book of God, whereas quadrivium was to cultivate the literacy for reading the second book of God.

An English word "law" stemmed from the past participle of an old form of "lay", which is etimologically synonym with "legen" of German language. If "law" is the past participle, namely a passive form, then there must be an agent that "laid". The agent was God. Now that God laid every part of Nature as it is, things are 
"laid" in the ordered form, which we can grasp as "law". In German, the counterpart for "law" is "Gesetz", which is of course the past participle of "setzen". In this case it is quite clear that the agent who "setzen" is God.

These etimological surveys may also show us that Nature created by God was regarded to be the book where man can read His will and His Design.

\section{Knowledge in the Renaissance 2}

The aforementioned characteristics of higher learnings did not change even at universities in "modern" era, which according to my hypothesis is not "modern" but "late Renaissance". In the 16th and 17th centuries, many "scientists" such as Kepler, Galileo, Newton and so on appeared. They are now counted as scientists today. Their knowledge pursuing activities, however, were still embedded in the framework of Christian worldview. Admittedly a part of their works, extracted from their whole systems of knowledge, may well be considered to be scientific, for Newtonian law of motion, without any surrounding theories of his philosophical and theological framework, is almost the same as we now know as in Newtonian mechanics. That is why Newton is now called a scientist. But for Newton himself the extracted fragment of law of motion would have had no meaning.

As I mentioned before, in mid 15th century, the West encountered again a new set of ideas which were foreign and new, and paganistic to the Western intellectuals of those days. Some of them refused to accept, but some did not. Those who accepted them were more or less unsatisfied with the rationality-oriented scholasticism and wanted to reorganize the world of knowledge and learnings. The newly introduced ideas and theories such as Hermeticism, Cabalism and many other mystical and symbolistic philosophical ideas played the role of trigger for them to creat a new theological system by means of combining the ideas with thier Christian theology.

Let me take Copernican theory. When he was a student at the University of Cracow, one of the colleagues of M. Ficino at Academia Platonica in Florence came to the university with Ficino's De sole et lumine, which was an amalgamation of Neo-Platonistic interpretation of universe with Judeo-Christian theology. In that the sun cult in the Hermetic and Neo-Platonistic philosophy was interpreted by the Genesis story. God created light on the first day of His Creation, which means light is most directly created creature and closest to God. We are not allowed to worship any other things than God Himself, and the sun should not be an object of worship. Yet we should also admit that the sun, the origin of light, is most sacred among creatures. The sun emanates light and heat as well as other abstract rays, which pierces everything in the universe gently just as love of God reaches and pierces everything He created. Copernicus succeeded this idea from Ficino and thought 
that the sun should not be placed by God any other place than at the center of the universe. Thus he envisaged to create a theory of planetary motion in which the sun is placed at the center of the universe.

Admittedly the Copernican helio-centric model, if it is extracted independently from his broader theory on the universe, and interpreted only as a theory which proposes the earth's rotations instead of the sun's rotations, is closer to our scientific planetary model than the Ptolemaic geo-centric model. It is deniably true. Yet we have to admit that his helio-centric model was only an ingredient of his whole theological theory, without which the isolated helio-centric model would have made no sense to him.

Moreover, we tend to discriminate Copernicus, Kepler, Galileo, Hravey and Newton from R. Fludd, Paracelsus, J. Andreae, because the members of the former group are "scientists", while the ones of the latter are not. Yet it would be clear, if we take this period as above-defined Renaissance process, that the alleged distance between the two groups is quite small or none. Fludd tried to renew the scholasticism and substitute it by a fresh theological worldview based on the NeoPlatonistic philosophy. He was willingly to accept Harveian blood circulation theory, because he had already proposed, before Harvey, a theory of inner circulation of human body. Paracelsus proposed chemical treatments for syphilis patients, or tried to apply an idea of public health to the workers of mining, many of whom were suffering from the respiratory diseases.

Of course, I do not mean to say that then Fludd, Paracelsus and other who are included in the latter group should be treated as modern scientists. On the contrary, they are as typical, as Renaissance philosophers, as Copernicus, Kepler, Galileo and Newton. They were basically equipped with same intention, same intellectual atmosphere, and same philosophical attitudes. Thus what I want to say here is quite simple. All of them were not scientists but Renaissance philosophers. All that they proposed were not scientific but philosophical and theological.

\section{Secularization Revolution}

Situation of the Western intellectuals drastically changed in the 18th century, the era of Enlightenment. One of the main drives of the Enlightenment was to liberate man from the fetters of Christianity. This was carried out in every corner of European society. In the Grand Revolution, which is the acme of Enlightenment, even the calender system based on the seven day week was discarded, because the custom of holiday of every seven days stemmed from the Judeo-Christian faith.

The world of knowledge and learnings could not escape from the influence of general tendency of secularization in the 18th century. Knowledge was also to be secularized. In this context, the words "secular" and its opposite "sacred" shall not 
convey any value judgement. "Sacred" represents the stance for knowledge where everything in the world cannot be described and explained thoroughly without referring to the Creator, while "secular" stands for the stance where the referrence to God is in principle needless to describe and explain the things in the universe. Through the endeavours of the Enlightenment philosophes, theologico-philosophical systems of knowledge in the past were deconstructed one by one, and reorganized without referring to any theological interpretations. The episode on Laplace illustrates this process symbolically. Laplace gifted his Mechanique celeste to Napoleon, and Napoleon, after having read it, complained that in the book he had never encountered the word God, whereas the book deals with the universe and He is the Creator of the universe. Laplace answered to him that for his theory it was absolutely needless, useless, and meaningless to refer to God.

When knowledge itself is secularized, then for what aim or goal does man pursue knowledge? Prior to the end of the 17th century, knowledge pursuing was aimed at better understanding of the Holy Design, and God's will. At universities people intended to study and be trained how to read the Holy Scripture as well as the second book of God. Now that knowledge was disengaged from such Christian theological frameworks, some new goals should be set and fostered for getting knowledge.

There were several kinds of responses to this problem raised in late 18th century, which can be categorized into three types. One may be called French type, and another German and the last British, although these names are only for categorization because actually in France one can also see other two to some extent, and in Germany and Britain vice versa. In French type knowledge is regarded as potency to cope with practical problems. Knowledge is valuable because of its utility. In other words knowledge pursuing began to be aimed at achieving ability to resolve problems and overcome difficulties within this mundane world. It is easy to see here the prototype of the present concept of science and technology.

By German type what I mean is the idea of knowledge for knowledge. Knowledge is worth pursuing because it is by itself valuable. One should not pursue knowledge for some other purposes than just getting and integrating knowledge. Knowledge itself has its own value. This idea on knowledge was mostly realized the newly established Humboldtian universities which began to spread throughout the 19th century not only within the German speaking areas but also more or less in other European countries and some other districts as Japan. One can see here the ivory tower image of university.

In 19th century Britain, knowledge and learnings were redefined as the basic requirement for gentleman. A gentleman should be able to quote a line of Shakespear's drama, of Keat's poem, to read the texts of Aristotle or Plato in Greek or at least in Latin, to talk on political philosophy of Hobbes, to identify a plant by the 
nomenclature, and to give an elegant proof for a theorem of non Euclidean geometry or of Maxwellian electro-magnetic mechanics. Modern British concept of knowledge lingered on generalism or universalism and far from specialism. The attitude toward the word "scientist" of Th. Huxley seems quite natural in the context of such an intellectual milieu of the British academic community.

Whatever the new type of response to the alteration of the nature of knowledge may be, knowledge in the West could not afford to retain its sacred character in the end of the 18th century. Knowledge, once deconstructed, was to be reorganized to shape an appropriate form to each of the newly established goals.

Knowledge of French type was unable to be pursued at universities even in France. Thus a new type of higher educational institution, École polytechnique was inaugurated in the midst of the Grand Revolution. Copies of this new institution were gradually spread in Europe during the 19th century. In the U.S., an act called the Morrill Act came into effect in 1862, which resulted in the establishment of the land-grant colleges in almost every state. The colleges were often called A \& M's, which means Agricultural and Mechanical Colleges. They were outside of the university system, within which only the ivy league universities were counted at that time.

Then in what situation Western universities stand facing with the revolutionary change of the concept of knowledge and learnings? To answer this question, another factor should be referred to. That is the emergence of the concept of civilization.

\section{Rise of the Concept of Civilization}

The word "civilization" was coined in early 18th century. Needless to say, it consists of "civis" (state, citizen or urbanism) and a suffix "ize". Behind this word, therefore, an idea that man should cultivate nature by himself into artificially governed and controlled state. Nature, as far as left wild, is only savage and uncivilized. She is useful and gives benefits to man, only when she is cultivated, dominated and cotrolled by man. We can say that this is the undercurrent ideology of the coinage of "civilization".

In some repects, the emergence of such an idea was one of the results of the Secular Revolution above-mentioned. During the process of the Secular Revolution, God, the Creater and the Dominator of this world, was gradually put aside and eventually killed in every aspect and field of European society. Once a sorid triad hierarchy of God Man-Nature was retained. Now this hierarchy was substitued by another binominal hierarchy of Man and Nature. It means Man takes the place of God, the dominator, over Nature. Nature should be dominated by man. Man is the master of Nature. 
If this ideology is taken for granted, the first thing that man is supposed to do is to disengage from Nature, to become independent from Nature. In 18th century Europe, the disengagement of man from Nature proceeded rapidly. Man enbedded in Nature and left as she does is only uncivilized. Man independent and selfdependent from the powers of nature is evaluated as civilized.

Thus man's disengagement from nature was almost inevitable process of civilization. Now the bifurcation of man and nature took place in full scale. On the one hand there is nature from that man has left behind and is ready to be dominated by man, and on the other is the world of artificiality, by that I maen the world of man, individuals and communities, and their conducts, among which to dominate nature is included. Of course, this process was not fully carried out in two respects. One reservation is that man must remain in Nature as a natural species. It is not deniable that man is in a sense one of animals, and in that respect man cannot be fully disengaged from nature. The other reservation is that it is also undeniable for the world of artificiality to be dominated, not fully but partially, by nature. Human conducts are often actuated and dominated by biological, or natural, drives and urges, such as sexual desire, appetite and so on. These natural desires and drives, which are often called the second nature, should be strictly controlled by man's reason, just as the first nature, as it were, should be dominated and controlled by man. In any case, the disengagement of man from nature resulted in the confronting scheme of man vis-a-vis nature.

While this ideology of civilization was permeating and being disseminated in the West, the reorganization of knowledge and learnings afore-mentioned took place. As a result, knowledge was reorganized in terms of the confronting scheme of man versus nature. It is not an accident that the classification of Kulturwissenschaft and Naturwissenschaft emerged in 19th century Germany, and that in England of the same period the word "science" began to designate solely "knowledge on nature". Sociology, political sciences in contemporary sense, cultural and natural anthropology, philosophy in today's sense also emerged in the 19th century on the one hand, and physics as a subject of natural sciences, and many other disciplines of knowledge on nature did on the other. It is again not an accident that $W$. Whewell coined the words, "scientist" and "physicist" in the first half of that century. Only through this process, science was scientized.

Once science had been scientized, one should and could shape the historical past in that perspective. Thus theories of Copernicus, Kepler, Galileo and Newton, in which one could recognize many "scientific" ingredients, were categorized as "science" or "scientific". They began to be counted as "scientists". Some historians of "science" such as J.W. Draper wrote books in which they framed heroic stories of the "scientists" who fought for "science" and against religious dogmas. 


\section{Conclusion}

Usually it is believed that modern science appeared in the 17th century in the West. When about five decades ago A. Koyre, H. Butterfield and so on proposed the concept of the Scientific Revolution, through which knowledge and learnings of Greco-Romano tradition were substituted by modern scientific theories, it was out of the question whether the theories put forward by Copernicus, Kepler, Galileo and Newton were "scientific" or not.

By the present survey, it may be made clear that we can raise the question to that kind of historical interpretation with sufficient legitimacy. Admittedly we can find "scientific" ingredients in them, if they are extracted from the whole architecture of their theories. Yet the whole archiecture itself cannot be called 'scientific' at least in today's sense. In that respect, it would be wrong or at least misleading, if we can say that science emerged through 17th century Scintific Revolution.

Only through the Secular Revolution, and only through the Civilization process, as it were, knowledge in the West was reshaped and reorganized into a new constellation, as a result of which science emerged. That was the scientization of science viewed from a perspective of history of ideas. 